\title{
PENGGUNAAN MODEL GROUP INVESTIGATION UNTUK MENINGKATKAN BERPIKIR KRITIS SISWA SMP
}

\author{
Eka Vasia Anggis \\ Fakultas Keguruan dan Ilmu Pendidikan, Universitas Wiralodra, \\ Jl. Ir. H. Juanda KM 3 Indramayu, \\ e-mail: ekasingga@gmail.com
}

\begin{abstract}
Group Investigation model is one of cooperatif metode that can grows critical student from directly experience. Based on observation in SMP 1 Indramayu 2016 were $40 \%$ the group was less colaboration, 60\% evidences was less, $65 \%$ students weren't connected problems each other, $55 \%$ decision hadn't most alternative problem solving to be collected.This aim research to descript critical thingking used group investigation model. Research metode qualititave descriptive, Research parameter is critical skill student and these indicator were problem indentifiy, argument analize, definition, finding source, observasion and result, mind based consideration ability integration to defend decision. Instrument research was quisioner. Result study from quisioner were $78 \%$ was good, $71 \%$ was enough. Conclusion was critical thinking skill can be used in group investigation model.
\end{abstract}

Keywords: Group Investigation model, Critical Thingking Model.

\section{PENDAHULUAN}

Pendidikan merupakan hal yang paling diperhatikan oleh pemerintah di Indonesia. Menurut UU No. 20 Tahun 2003 tentang sistem pendidikan nasional. Pendidikan merupakan upaya yang merupakan kesadaran dalam diri dan adanya perencanaan sehingga dapat menumbuhkan susasana pembelajaran yang kondusif sehingga siswa dapat menumbuhkan potensinya baik dari segi keagamaan, pengendalian diri sendiri, intelektual, karakter yang sehat, kemampuankemampuan yang ditumbuhkan dari diri siswa.

Namun sejalan dengan harapan pemerintahan tentang pendidikan, masih terdapat kesenjangan yang belum bisa mengarah pada tujuan pendidikan nasional Indonesia. Hal ini berdasarkan dari PISA (Programme for International Student
Assesment) tahun 2009, Indonesia berada di peringkat ke-61 dari 65 negara dengan skor 371, tahun 2012, Indonesia berasa di peringkat 64 dari 65 peserta dengan skor rata-rata 375 , sedangkan skoir rata-rata internasional 500 (Leward dan Hirata, 2013). Hal ini sangat memprihatinkan sehingga diperlukan adanya peningkatan pembelajaran baik proses maupun hasil.

Berdasarkan hasil observasi lapangan di SMP 1 Indramayu (2016) didapatkan data meliputi $40 \%$ kurang kesadaran dalam suatu kelompok untuk saling bekerjasama, 60\% kurang adanya fakta-fakta dalam mendapatkan pengetahuan, $65 \%$ belum bisa menghubungkan antara masalah satu dengan yang lain, 55\% keputusan yang diambil belum adanya berbagai alternatif solusi masalah lainnya untuk dipilih mana yang terbaik. Tujuan penelitian untuk menumbuhkan kemampuan berpikritis siswa 
dengan menggunakan Grup Investigation. Belajar merupakan hal yang tak dapat dipisahkan dalam persoalan di kehidupan sehari-hari. Pemerintah berupaya mengembangkan pendidikan bagaimana seseorang bisa memutuskan permasalahan dengan alternatif terbaik.

Berdasarkan hasil observasi, terdapat beberapa permasalahan yang diperlukan pemecahan solusi, disolusi tersebut adalah pemilihan model. Hal ini dijelaskan dalam Nurhadi,dkk, (2004:61) pembelajaran kooperatif adalah pembelajaran yang secara sadar dan sistematis mengembangkan interaksi antar siswa sebagai latihan hidup di dalam masyarakat.

Rusman (2012) menyatakan bahwa karakteristik pembelajaran kooperatif adalah pembelajaran secara tim, didasarkan pada manajemen kooperatif, kemauan dan keterampilan untuk bekerja sama. Jadi, dengan adanya kerjasama siswa akan saling bertukar pikiran, beradu argumen yang dapat menumbuhkan rasa ingin tahu. Hal ini merupakan langkah awal siswa untuk belajar berpikir ingin menemukan jawabannya dengan penyelidikan, adu argumen, menggunakan dasar pemikiran, menghubungkan dengan teori yang telah diketahui sehingga belajar menjadi lebih bermakna.

Salah satu pembelajaran kooperatif adalah model Grup Investigation. Model tersebut memiliki langkah-langkah yangmana dieberi pertanyaan untuk stimulasi awal dalam pembelajaran. Pertannyaan diberikan akan dijawab oleh siswa melalui investigasi. Peran guru dalam model pembelajaran ini adalah membantu siswa dalam menjalankan proses penyelidikan, guru sebagai narasumber, pemandu proses atau kegiatan pembelajaran, konsultan, dan manajer di kelas, serta seorang fasilitator. Baharuddin
\& Wahyuni (2009) berpendapat bahwa teori Vygotsky berhubungan dengan belajar, komunikasi dan kerjasama antar individuindividu sebelum akhirnya proses belajar tersebut menjadi suatu pengetahuan yang berada dalam individu itu sendiri. Oleh karena itu, Tujuan penelitian ini berhubungan dengan Grup Investigation. untuk meumbuhkan kemampuan berpikritis siswa.

\section{METODE PENELITIAN}

Penelitian ini merupakan jenis penelitian deskriptif kualititatif memberikan penjabaran kemampuan kritis siswa dalam belajar biologi dengan menggunakan model GI. Materi yang digunakan adalah pencemaran lingkungan dan penanganannya. Subyek penelitian adalah siswa kelas VII SMP 1 Indramayu Semester ganjil Tahun ajaran 2016/2017, Materi tentang pencemaran air. Sample kelas adalah VII A (30 orang) dan VII B (30). Pelaksaanaan sebanyak 3 kali pertemuan. Instrumen penelitian yaitu kuisioner observasi kemampuan berpikir kritis siswa pada tahap persiapan, praktikum, diskusi. Indikator yang diteliti meliputi identifikasi masalah, analisis argumen, definisikan istilah, menetapkan sumber relevan, obeservasi dan hasilnnya, pertimbangan dasar pemikiran, intergrasi kemampuan dalam mempertahan keputusan (Ennis, 1991). Teknik pengumuplan data dengan kuisioner dirancang beradasarkan indiakator berpikir kritis dalam 10 pertanyaan. Angket terdiri tas pertanyaan postif dan negatif. Nagket disusun dengan alternatif jawaban Sangat Setuju (SS), Setuju (S), Kurang Setuju (KS), Tidak Setuju (TS). Teknik analisis data berupa penjabaran deskriptif hasil rerata dari kuisioner. 


\section{HASIL DAN PEMBAHASAN}

Berdasarkan kuisioner dari Tabel 1 didapatkan hasil berpikir kritis siswa tergolong baik dengan rerata $77,11 \%$. Pada tiap pertemuan terjadi peningkatan. Indikator berpikir kritis tertinggi ada pada point nomor 6 (indikator observasi dan hasilnya). Hal ini dikarenakan model GI terdapat tahap investigasi. Siswa terdorong untuk melakukan observasi ke lapangan untuk melihat kenyatan atau fakta yang ditemukan sehingga fakta-fakta yang ditemukan dihubungkan dianalisis dengan teori sampai menemukan pengetahuan baru. Hal ini dikarenakan adanya tahap investigasi dari GI yang mendorong siswa untuk terjun ke lapangan menginvestigasi daerah-daerah yang mengalami pencemaran air. Berdasarkan hasil investigasi siswa akan mengetahui jenis, penyebab dari pencemaran. Adapun langkah model pembelajaran GI menurut Slavin (2010) meliputi 1) stahap pengelompokkan dan pemilihan topik, 2) tahap perencanaan, 3) tahap investigasi 4) tahap organisasi , 6) tahap presentasi, 7) evaluasi.

Tabel 1. Rerata Berpikir Kritis Siswa pada Setiap Pertemuan

\begin{tabular}{|c|c|c|c|c|c|c|}
\hline \multirow[t]{2}{*}{ No } & \multirow{2}{*}{$\begin{array}{l}\text { Indikator berpikir } \\
\text { kritis }\end{array}$} & \multicolumn{3}{|c|}{ Sikap ilmiah/pertemuan } & \multirow[t]{2}{*}{$\mathbf{P}(\%)$} & \multirow[t]{2}{*}{ Kategori } \\
\hline & & I & II & III & & \\
\hline 1 & $\begin{array}{l}\text { identifikasi } \\
\text { masalah }\end{array}$ & 75 & 77 & 79 & 77 & $\mathrm{~B}$ \\
\hline 2 & analisis argumen & 74 & 76 & 78 & 76 & B \\
\hline 3 & definisikan istilah & 76 & 76,5 & 80 & 77,5 & $\mathrm{~B}$ \\
\hline 4 & $\begin{array}{l}\text { menetapkan } \\
\text { sumber relevan }\end{array}$ & 76 & 78 & 78 & 77,3 & $\mathrm{~B}$ \\
\hline 5 & $\begin{array}{l}\text { pertimbangan dasar } \\
\text { pemikiran } \\
\text { (hipotesa) }\end{array}$ & 76 & 77 & 79 & 77,3 & B \\
\hline 6 & $\begin{array}{ll}\text { obesrvasi dan } \\
\text { hasilnnya }\end{array}$ & 78 & 79 & 79,8 & 78,9 & B \\
\hline 7 & $\begin{array}{l}\text { kemampuan dalam } \\
\text { mempertahan } \\
\text { keputusan }\end{array}$ & 77 & 78 & 79,5 & 78,1 & $\mathrm{~B}$ \\
\hline & $(\mathrm{P} \%)$ & 76 & 77,4 & 78 & 77,11 & \\
\hline
\end{tabular}

Keterangan:

$\mathrm{B}=$ Baik

Pertemuan I : Persiapan

Pertemuan II : Pelaksanaan

Pertemuan : Diskusi

Indikator berpikir kritis tertinggi kedua adalah indikator dalam mempertahankan keputusan. Siswa mulai memiliki rasa percaya diri dalam berargumentasi, percaya diri tentang hasil yang dipelajari. Hal ini sesuai dengan Zingaro (2008) yang menyatakan bahwa beberapa efek positif dari GI adalah siswa dalam kelas GI memiliki kemampuan untuk tampil lebih baik dan memiliki kemampuan untuk mengajukan pertanyaan tingkat tinggi. Selain itu, GI juga memiliki efek positif terhadap siswa yaitu memiliki kemampuan kooperatif yang lebih baik, bahkan dengan anggota kelompok lain, siswa memiliki kemandirian yang besar, mampu mengekspresikan diri dengan lebi baik dan memiliki rasa tanggung jawab. siswa untuk merencanakan, menginvestigasi, mengorganisasi sehingga siswa dalam 
berargumen akan penemuannya memiliki rasa kepercayaan diri yang kuat dilandaskan oleh fakta dan teori serta dasar pemikiran mereka.

Berdasarkan pertemuan, point tertinggi terdapat pada pertemuan ketiga (diskusi). Hal sesuia dengan kelebihan Model Group Investigation menurut Sharan (dalam Sumarmi, 2012) antara lain 1) siswa dalam GI cenderung menyumbangkan ide, 2) gaya bahasa dan kerjasama dapat diobservasi, 3) siswa dapat belajar lebih kooperatif, 4) GI mendorong siswa berpartisipasi aktif, 6) GI meningkatkan performance siswa dan kepercayaan diri pada siswa itu sendiri. Menurut Mitchell, Montgomery, Holde \& Stuat (2008) Model GI merupakan model pembelajaran sesuai dengan teori konstruktivisme. Model yang menekankan pada interaksi individu dalam suatu kelompok untuk saling bekerjasama sehingga tujuan pembelajaran dapat tercapai dengan baik. Hal ini sesuai dengan prinsip teori pembelajaran konstruktivisme Vygotsky yang menekankan pada interaksi individu satu dengan yang lain.

\section{SIMPULAN DAN SARAN}

\section{Simpulan}

Kesimpulan yang didapatkan dari penelitian Jigsaw berbasis LS adalah

1. Hasil berpikir kritis siswa tergolong baik dengan rerata $77,11 \%$.

2. Rerata persentase indikator tertinggi pertama dan kedua pada observasi dan hasilnya, kemampuan dalam mempertahankan keputusan.

3. Pada tiap pertemuan terjadi peningkatan, pertemuan ketiga (3) memiliki persentasi $78 \%$. Hal ini merupakan pertemuan tertinggi daripada pertemuan satu dan dua

\section{Saran}

Sebaiknya dilakukan penelitian lanjutan GI dengan menggunakan penelitian tindakan kelas atau quasi experiment

\section{RUJUKAN}

Baharuddin \& Wahyuni, N.E. (2009). Teori Belajar dan Pembelajaran. Yogyakarta: Aruzz Media.

Ennis, Robert, 1881. Critical Thingking: A Streamlind Conception. Jurnal Thingking Filosofy, (online) 14:1. (http://www.critical thingking.net/testing)html), diakses 9 Desember 2014.

Leward, B.C. \& Hirata, D. 2011. An overview of $21^{\text {st }}$ Century skills. Honolulu: Kamehameha SchoolResearch \& Evaluation.

Mitchell, G.M., Montgomery, H., Jolder, M., \& Stuart. (2008). Group Investigastion as a Cooperative Learning Strategy: An integrated Analysis Literature. The Alberta Journal of Education Research, 54 (4), 388-395.

Nurhadi, Y., Burhan \& Senduk, A.G. 2004. Pembelajaran

Kontekstual (Contextual Teaching and Learning/CTL) dan Penerapannya dalam KBK. Malang: UM Press.

Slavin,R.E.2010. Cooperatif Learning: Teroi, Riset dan Praktik. Bandung: Nusa Media.

Sumarmi.2012. Model model Pembelajaran geografi. Malang: Aditya Media.

Zingaro, D. (2008). Group Investigation Theory dan Practice. (online). (www.danielzingaro.com) diakses Oktober 2015. 